Journal of Animal and Veterinary Advances 11 (11): 1901-1906, 2012

ISSN: $1680-5593$

(C) Medwell Journals, 2012

\title{
IGF-1 Protects Myocardial Cells from ROS Stress-Induced Apoptosis via Up-Regulating ARC
}

\author{
Zhaofang Xi, Haibao Zhu, Dongyang Liu, Liming Wu and DingZong Guo \\ College of Veterinary Medicine, Huazhong Agricultural University, 430070 Wuhan, China
}

\begin{abstract}
Insulin-like Growth Factor-1 (IGF-1) and Apoptosis Repressor with Caspase recruitment domain (ARC) play an important role in regulating apoptosis. Although, the precise mechanisms of IGF-1 and ARC in this process have not been defined, they have similar anti-apoptotic effects in myocardial cells, suggesting that these effects are related. Researchers found that $\mathrm{H}_{2} \mathrm{O}_{2}$ can induce ARC reduction in $\mathrm{H} 9 \mathrm{C} 2$ cells but IGF-1 can change this trend. To clarify this trend using immunofluorescence and immunoblot analysis, researchers found that LY294002 (PI3K inhibitor) blocked IGF-1 up-regulation of ARC protein and blocked the protective effect of IGF-1 on myocardial cell apoptosis induced by oxidative stress. These results indicate that IGF-1 up-regulates ARC protein expression via the PI3K pathway which protects against myocardial cell apoptosis induced by oxidative stress.
\end{abstract}

$\underline{\text { Key words: } \mathrm{H} 9 \mathrm{C} 2 \text { cells, hydrogen peroxide, IGF-1, ARC, apoptosis, China }}$

\section{INTRODUCTION}

Insulin-like Growth Factor I (IGF-I), a 70-amino acid polypeptide of $7.5 \mathrm{kDa}$ is a major determinant of proliferation and apoptosis and is a key component in blood along with high-affinity binding proteins (Baserga, 2004). Previous reports have demonstrated a defensive action of IGF-1 against ROS stress-induced apoptosis in myocardial cells (Buerke et al., 1995). Increased expression of the anti-apoptosis proteins, $\mathrm{Bcl}-2$ and $\mathrm{Bcl}-\mathrm{xL}$, two members of the $\mathrm{Bcl}$ family of proteins has been postulated to be the reason for IGF-1 inhibition of apoptosis (Kim et al., 2002). Although, Bcl-2 and Bcl-xL promote cell survival they are expressed at low or undetectable levels in heart muscle (Miyatake et al., 1998).

The protein apoptosis repressor with caspase recruitment domain (ARC) contains a CARD domain which functions as an inhibitor of apoptosis and has been widely investigated (Koseki et al., 1998; Ekhterae et al., 1999). ARC is highly and predominantly expressed in long-lived tissues such as the heart, skeletal muscle and brain (Koseki et al., 1998). Indeed, ARC is the first antiapoptotic protein identified so far to be highly expressed in cardiac and skeletal muscle tissues (Mercier et al., 2008). ARC selectively interacts with the initiators caspases- 2 and caspases- 8 , thereby attenuating death receptor-induced (CD95, TNFR1 and DR3) or adaptorinduced (FADD, TRADD and CLARP) apoptosis
(Koseki et al., 1998; Ekhterae et al., 1999). Because of the wide involvement of IGF-1 and the central role of ARC in regulating the apoptotic program in cardiomyocytes, it is reasonable to speculate that there is a correlation between IGF-1 and ARC in their role as apoptosis inhibitors. The goal of this study is to investigate the relationship between IGF-1 and ARC in $\mathrm{H} 9 \mathrm{C} 2$ cells under the oxidative stress environment.

\section{MATERIALS AND METHODS}

Cell treatment and viability assay: $\mathrm{H} 9 \mathrm{C} 2$ cells (ATCC, CRL-1446 ${ }^{\mathrm{TM}}$ ) were maintained in Dulbecco's Modified Eagles Medium (DMEM) supplemented with 10\% Fetal Bovine Serum (FBS) at $37^{\circ} \mathrm{C}$ with $5 \% \mathrm{CO}_{2}$.

Hydrogen peroxide $\left(\mathrm{H}_{2} \mathrm{O}_{2}\right)$ treatment was performed as described previously (Abmayr et al., 2004). In brief, the cultured cells were incubated at $37^{\circ} \mathrm{C}$ in treatment media (complete media excluding $\mathrm{H}_{2} \mathrm{O}_{2}$, IGF-1 or LY294002) for $24 \mathrm{~h}$ prior to the addition of various reagents. The reaction was stopped by removing the media containing these reagents. Cell death was determined by trypan blue exclusion and the number of trypan blue-positive and negative cells was counted on a hemocytometer.

Immunofluorescence: $\mathrm{H} 9 \mathrm{C} 2$ cells cultured on glass coverslips were fixed with $1 \%$ paraformaldehyde overnight at $4{ }^{\circ} \mathrm{C}$ and permeabilized in $0.05 \%$ Triton X-100

Corresponding Author: DingZong Guo, College of Veterinary Medicine, Huazhong Agricultural University, 430070 Wuhan, China 
for $5 \mathrm{~min}$ at room temperature. After three washes with PBS-Tween 20, cells were blocked with 1\% BSA for $2 \mathrm{~h}$ followed by incubation with primary antibody against ARC (abcam Co., Ltd. San Francisco USA) overnight at $4^{\circ} \mathrm{C}$. Cells were then washed with PBS followed by incubation with Alexa Fluor 488 anti-rabbit antibody (Invitrogen Co., Ltd. New York USA) for $1 \mathrm{~h}$ at room temperature. Then, the nucleus were stained with Hoechst $33342\left(1 \mathrm{ug} \mathrm{mL}^{-1}\right.$ ) (Beyotime Co., Ltd. Jiangsu China) for $10 \mathrm{~min}$.

Immunoblot analysis: Cells were lysed for $1 \mathrm{~h}$ at $4^{\circ} \mathrm{C}$ in a lysis buffer (20 mM Tris pH 7.5, 2 mM EDTA, $3 \mathrm{mM}$ EGTA, $2 \mathrm{mM}$ Dithiothreitol (DTT), $250 \mathrm{mM}$ sucrose, $0.1 \mathrm{mM}$ phenylmethylsulfonyl fluoride and 1\% Triton $\mathrm{X}-100$ ) containing a protease inhibitor cocktail (Sigma Co., Ltd. Missouri, USA). Samples were subjected to $12 \%$ sodium dodecyl sulfate-polyacrylamide gel electro-phoresis and transferred to nitrocellulose membranes.

Equal protein loading was controlled by Ponceau Red staining of membranes. Blots were probed using primary antibodies. The anti-ARC antibody $(1: 1,000)$ was from Abcam Inc (San Francisco USA). The rabbit immunoglobulin G control (1:200) was from Antigenix America Inc (New York, USA). After four washes with PBS-Tween 20, horseradish peroxidase-conjugated secondary antibodies $(1: 2,000)$ were added (Boster Co., Ltd. Wuhan, China). Antigen-antibody complexes were visualized by enhanced chemiluminescence (Thermo Co., Ltd. Illinois USA).

Design and transfection of siRNA: ARC siRNA oligos were synthesized by Qiagen Inc (Dusseldorf Germany). The coding sequence of siRNA oligos was ARC 5'CCCAGTACCGCTGGAAGTGAA-3' and siRNA oligos were transfected into cells using Lipofectamine ${ }^{\mathrm{TM}} 2000$ (Invitrogen Co., Ltd. New York, USA) following the manufacturer's instructions. Briefly, cells were plated in medium without antibiotics the day before transfection so, that a $50-70 \%$ confluence was achieved at the time of transfection. The siRNA oligos $(100 \mathrm{nM})$ were used for each transfection.

Statistical analysis: Data are expressed as the mean \pm SEM. The significance of differences between samples was analyzed by one-way ANOVA. For each time point or experiment, triplicate or quadruplicate samples were analyzed. A $p<0.05$ was considered statistically significant.

\section{RESULTS AND DISCUSSION}

ARC down-regulation occurs upon stimulation with hydrogen peroxide: The expression levels of ARC were analyzed to assess its role in regulating cell death induced by hydrogen peroxide. As shown by immunofluorescence in Fig. 1, after treatment with hydrogen peroxide, ARC protein expression was very low compared with that in the control group. Moreover, researches also, observed that the IGF-1 inhibited the down-regulation of ARC induced by hydrogen peroxide. To confirm this finding, Western blotting was employed to detect $\mathrm{ARC}$ expression. Researchers found that ARC protein levels were down-regulated after hydrogen peroxide treatment (Fig. $1 \mathrm{~g}$ and $\mathrm{h}$ ). Increased concentrations of hydrogen peroxide led to decreased ARC expression. We also wished to determine whether ARC is able to affect cell fate upon stimulation with hydrogen peroxide. Researchers observed that $\mathrm{H}_{2} \mathrm{O}_{2}$ significantly induced the $\mathrm{H} 9 \mathrm{C} 2$ cells death (Fig. 1i). Knocking down ARC expression led to a significant increase in cell death compared with that in cells treated with $\mathrm{H}_{2} \mathrm{O}_{2}$ alone. Corresponding with the cell death, ARC expression level also decreased.

IGF-1 protects $\mathrm{H9C2}$ cells from $\mathrm{H}_{2} \mathrm{O}_{2}$-induced apoptosis via Up-regulating ARC: To demonstrate the relationship between IGF-1 and ARC expression, researchers investigated $\mathrm{ARC}$ expression from $\mathrm{H} 9 \mathrm{C} 2$ cells treated with IGF-1 at different concentrations and time points (Fig. 2a and b). We observed that IGF-1 significantly upregulated ARC expression in a dose-dependent and timedependent manner. IGF-1 significantly decreased cell death induced by $\mathrm{H}_{2} \mathrm{O}_{2}$ (Fig. 2d). IGF-1 also inhibited the decrease in ARC protein levels induced by $\mathrm{H}_{2} \mathrm{O}_{2}$ (Fig. 2c). These data indicate that ARC plays an important role in IGF-1 protection of apoptosis induced by $\mathrm{H}_{2} \mathrm{O}_{2}$ in $\mathrm{H} 9 \mathrm{C} 2$ cells. To further confirm this finding, siRNA was used to knockdown ARC expression. We found that siRNA (ARC) attenuated cell death induced by $\mathrm{H}_{2} \mathrm{O}_{2}$ even in the presence of IGF-1 (Fig. 2f). We also found that ARC protein levels were significantly down-regulated by siRNA (Fig. 2e).

LY294002 inhibits ARC expression induced by IGF-1: $\mathrm{PI} 3 \mathrm{~K}$ is an important signaling pathway for IGF-1 protection of cell survival. To confirm whether IGF-1 up-regulates the ARC protein expression through the PI3K pathway, we employed L Y294002 to inhibit the PI3K pathway. Researchers found that LY294002 increased cell death induced by the $\mathrm{H}_{2} \mathrm{O}_{2}$ even in the presence of IGF-1 

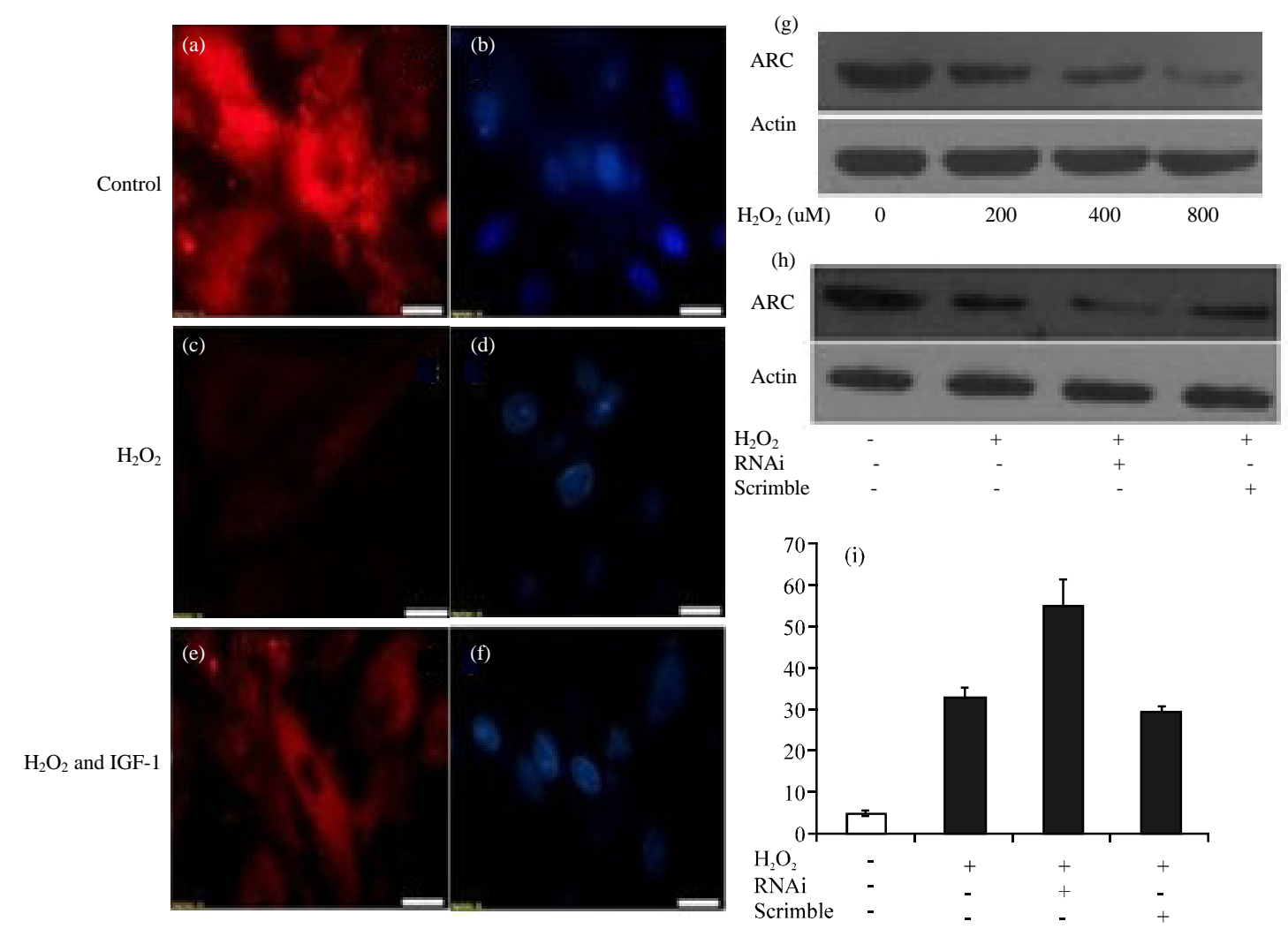

Fig. 1: ARC down-regulation occurs upon stimulation with hydrogen peroxide. Cells were either untreated or were treated with $\mathrm{H}_{2} \mathrm{O}_{2}\left(1 \mathrm{mM} \mathrm{mL}^{-1}\right)$ or IGF-1 $\left(100 \mathrm{ng} \mathrm{mL}^{-1}\right)$. a, c, e) Expression of ARC protein in H9C2 cells by IFA. b, d, f) The nucleus was stained by Hochest $33342\left(1 \mathrm{ug} \mathrm{mL} \mathrm{mL}^{-1}\right)$. g) Cells were either untreated or treated for $8 \mathrm{~h}$ with 200,400 or $800 \mathrm{uM} \mathrm{mL}^{-1} \mathrm{H}_{2} \mathrm{O}_{2}$ and ARC was assessed by western blotting. h) Cells were transduced with ARC siRNA $\left(100 \mathrm{nM} \mathrm{mL}^{-1}\right)$ and transduced cells were treated with $\mathrm{H}_{2} \mathrm{O}_{2}\left(1 \mathrm{mM} \mathrm{mL}^{-1}\right)$. Total protein was prepared and total ARC levels were determined by western blotting using anti-ARC antibodies. i) Cell viability was determined as described in the materials and methods

(Fig. 3b). Additionally when detecting ARC protein levels, we observed that the LY294002 inhibitor knocked down ARC protein expression induced by IGF-1 (Fig. 3a). These data strongly indicate that IGF-1-induced ARC protein expression is through the PI3K pathway.

Myocardial cells are highly differentiated cells that typically do not replicate after birth and loss of myocardial cells results in the loss of myocardial function (Kawano et al., 1994; Wakeno et al., 2006; Labovsky et al., 2010) which contributes to the development of heart failure (Ripa et al., 2006; Buerke et al., 1995), first found that IGF-1 is an important anti-apoptotic factor in a murine model of myocardial ischemic reperfusion by finding that IGF-1 could decrease myocardial apoptosis (Ibe et al., 2007). Other research groups have also demonstrated that overexpression of IGF-1 decreases myocardial cell death in a coronary artery ligation model (Leri et al., 1999; Yamashita et al., 2001). On the other hand, ARC is an apoptosis repressor (Hunter et al., 2007; Foo et al., 2007). It is highly expressed in cardiac tissues and cancer tissue (Li et al., 2008; Zhang and Herman, 2008).

Several lines of evidence suggest a protective role of ARC in cardiomyocyte apoptosis induced by ischemia and reperfusion (Zhang and Herman, 2008). In this study, we found that $\mathrm{H}_{2} \mathrm{O}_{2}$ down-regulated the ARC protein levels and that IGF-1 inhibited ARC expression by decreasing in response to stimulation with oxidative stress. Previous results have also shown that oxidative stress plays a major role in inhibition of ARC protein expression (Foo et al., 2007; Li et al., 2008). This research has clearly indicated a synergetic effect of IGF-1 on up-regulation of ARC expression. 
(a)



(b)
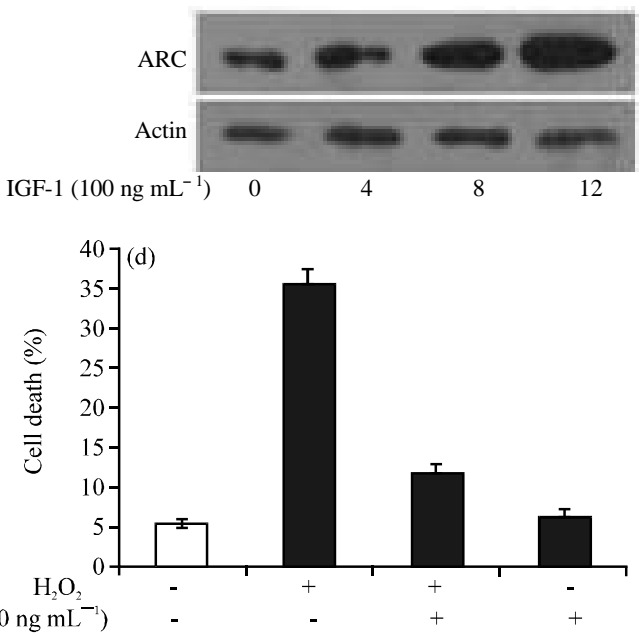

(c)


IGF-1 (100 ng mL $\left.{ }^{-1}\right)$

(e)

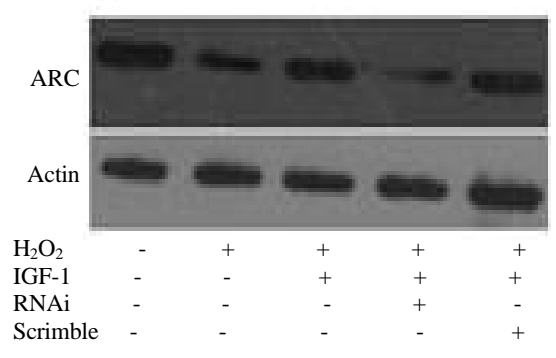

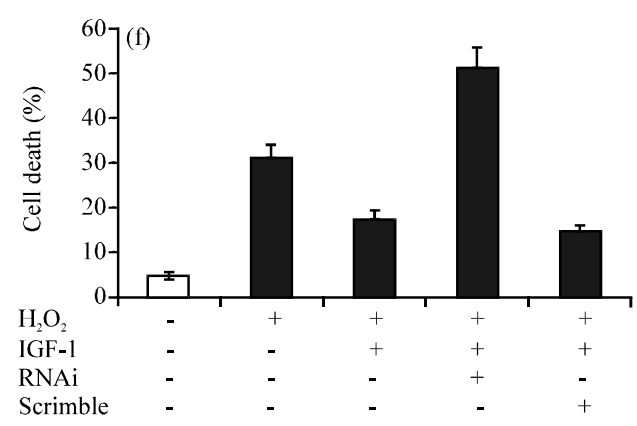

Fig. 2: IGF-1 protects $\mathrm{H} 9 \mathrm{C} 2$ cells from $\mathrm{H}_{2} \mathrm{O}_{2}$ induced apoptosis via up-regulating $\mathrm{ARC}$; a) Cells were treated with different

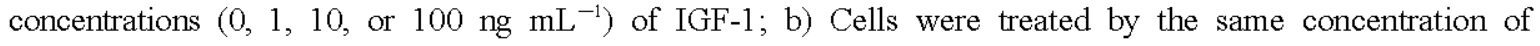
IGF-1 (100 ng mL $\left.\mathrm{mL}^{-1}\right)$ for different times $(0,4,8$ or $12 \mathrm{~h})$, c) Cells were untreated for $30 \mathrm{~min}$ with IGF-1 (100 $\left.\mathrm{ng} \mathrm{mL} \mathrm{mL}^{-1}\right)$ and then exposed to $\mathrm{H}_{2} \mathrm{O}_{2}\left(1 \mathrm{mM} \mathrm{mL}^{-1}\right)$ for $6 \mathrm{~h}$; e) Cells were transfected with ARC siRNA $\left(100 \mathrm{nM} \mathrm{mL}^{-1}\right)$, treated with IGF-1 (100 ng mL $\left.{ }^{-1}\right)$ and then exposed to $\mathrm{H}_{2} \mathrm{O}_{2}\left(1 \mathrm{mM} \mathrm{mL}^{-1}\right)$ for $6 \mathrm{~h}$. d, f) Cell viability was determined as described in the materials and methods. Cultures were lysed in lysis buffer and the isolated protein was determined using Western blotting analysis. Blots were stripped and analyzed for $\beta$-action to control for protein loading

ARC can block apoptotic cascades in multiple ways (Di Giovanni et al., 2004). ARC not only directs caspaseinhibiting functions but it can also interact with FADD or Bax (Zhang and Herman, 2008). In addition, it also inhibits cytochrome $\mathrm{c}$ release and maintains membrane potentials (An et al., 2009). Furthermore, ARC appears to be a calcium-binding protein and can suppress an intracellular $\mathrm{Ca}^{2+}$ increase, thereby blocking $\mathrm{Ca}^{2+}$-mediated apoptosis (Li et al., 2009) which can stimuli myocardial cell death via down-regulation of ARC protein expression (Abmayr et al., 2004). The present study results are consistent with these previous results. The presence of IGF-1 plays a dual role by inhibiting cell death as well as up-regulating the $\mathrm{ARC}$ protein expression under an oxidative stress environment. We also found that ARC knock-down induced a higher rate of cell death induced by oxidative stress even when IGF-1 was present. From these results we speculate that ARC plays an important role in IGF-1 protection against oxidative stress-induced myocardial cell apoptosis.

It is well documented that IGF-1 promotes cell survival and proliferation via a number of signaling mechanisms such as phosphatidylinositol 3-kinase (PI3-K) or Mitogen-Activated Protein Kinase (MAPK) (Stitt et al., 2004). In fact inhibition of PI3-K can directly result in apoptosis in some cell types (Subramaniam et al., 2005). Activated IGF-1R phosphorylates the signals via MAPK and PI3K-Akt pathways (Laurino et al., 2005).

These signals play important roles in cell proliferation and inhibition of apoptosis. In this study, researchers 
(a)

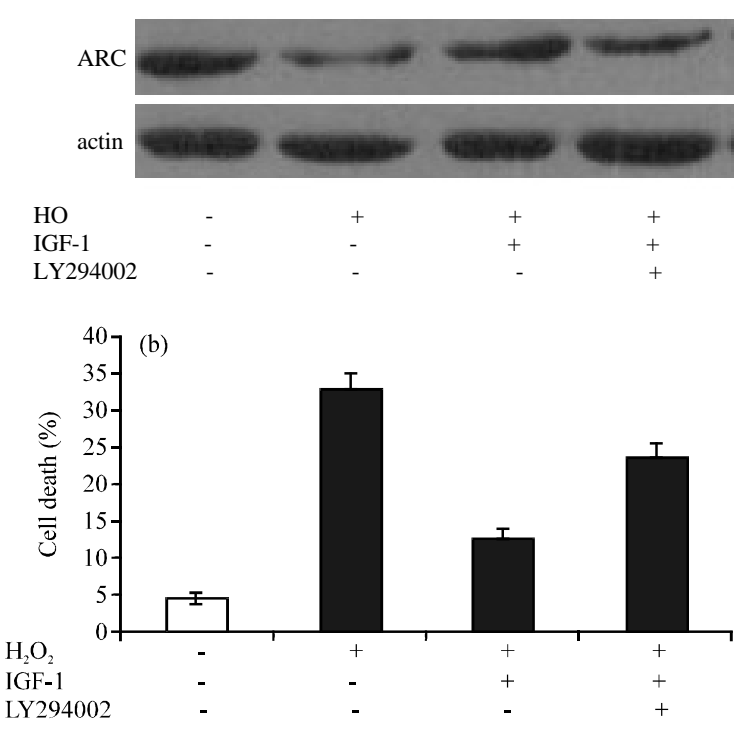

Fig. 3: LY294002 inhibits ARC expression induced by IGF-1. Cells were preincubated for $30 \mathrm{~min}$ with ly294002 (50 uM mL ${ }^{-1}$, PI-3K inhibitor) or IGF-1 (100 ng $\mathrm{mL}^{-1}$ ) and then treated with $\mathrm{H}_{2} \mathrm{O}_{2}\left(1 \mathrm{mM} \mathrm{mL} \mathrm{mL}^{-1}\right)$ for $6 \mathrm{~h}$; a) Total protein extracts were prepared and ARC levels were detected by immunoblot and b) Cell viability was determined as described in the materials and methods

found that PI3K inhibitor blocked IGF-1 up-regulation of ARC protein and it also blocked the IGF-1 protective action against apoptosis induced by oxidative stress in myocardial cells.

\section{CONCLUSION}

Researchers successfully demonstrated a correlation between IGF-1 and ACR protein expression under an oxidative stress environment. The results indicate that IGF-1 can up-regulate ARC protein expression via the PI3K pathway to protect against myocardial cell apoptosis induced by oxidative stress.

\section{ACKNOWLEDGEMENTS}

Researchers thank professor Jiakui Li for providing $\mathrm{H} 9 \mathrm{C} 2$ cells. This study was supported by the Research Fund for the Doctoral Program of Higher Education of China (20100146110001). Zhaofang $\mathrm{Xi}$ and Haibao Zhu are contributed equally to this research.

\section{REFERENCES}

Abmayr, S., R.W. Crawford and J.S. Chamberlain, 2004. Characterization of ARC, apoptosis repressor interacting with CARD, in normal and dystrophindeficient skeletal muscle. Hum. Mol. Genet., 13: 213-221.

An, J.F., P.F. Li, J.C. Li, R. Dietz and S. Donath, 2009. ARC is a critical cardiomyocyte survival switch in doxorubicin cardiotoxicity. J. Mol. Med., 87: 401-410.

Baserga, R., 2004. Targeting the IGF-1 receptor: From rags to riches. Eur. J. Cancer., 40: 2013-2015.

Buerke, M., T. Murohara, C. Skurk, C. Nuss, K. Tomaselli and A.M. Lefer, 1995. Cardioprotective effect of insulin-like growth-factor-I in myocardial-ischemia followed by reperfusion. Proc. Natl. Acad. Sci. USA., 92: 8031-8035.

Di Giovanni, S., A. Molon, A. Broccolini, G. Melcon, M. Mirabella, E.P. Hoffman and S. Servidei, 2004. Constitutive activation of MAPK cascade in acute quadriplegic myopathy. Ann. Neurol., 55: 195-206.

Ekhterae, D., Z.W. Lin, M.S. Lundberg, M.T.Crow, F.C. Brosius and G. Nunez, 1999. ARC inhibits cytochrome $\mathrm{c}$ release from mitochondria and protects against hypoxia-induced apoptosis in heart-derived H9c2 cells. Circ Res., 85: e70-e77.

Foo, R.S.Y., L.K.W. Chan, R.N. Kitsis and M.R. Bennett, 2007. Ubiquitination and degradation of the antiapoptotic protein ARC by MDM2. J. Biol. Chem., 282: 5529-5535.

Hunter, A.L., J.C. Zhang, S.C. Chen, X.N. Si, B. Wong, D. Ekhterae, H.L. Luo and D.J. Granville, 2007. Apoptosis repressor with caspase recruitment domain (ARC) inhibits myogenic differentiation. FEBS. Lett., 581: 879-884.

Tbe, W., A. Saraste, S. Lindemann, S. Bruder and M. Buerke et al., 2007. Cardiomyocyte apoptosis is related to left ventricular dysfunction and remodelling in dilated cardiomyopathy, but is not affected by growth hormone treatment. Eur. J. Heart. Fail., 9: 160-167.

Kawano, H., R. Okada, Y. Kawano, N. Sueyoshi and T. Shirai, 1994. Apoptosis in acute and chronic myocarditis. Jpn. Heart. J., 35: 745-750.

Kim, H.S., K. Shiraki and S.H. Park, 2002. Expression of survivin in CIN and invasive squamous cell carcinoma of uterine cervix. Anticancer Res., 22: 805-808.

Koseki, T., N. Inohara, S. Chen and G. Nunez, 1998. ARC, an inhibitor of apoptosis expressed in skeletal muscle and heart that interacts selectively with caspases. Proc. Nat. Acad. Sci., 95: 5156-5160. 
Labovsky, V., E.L. Hofer, L. Feldman, V.F. Vallone and H.G. Rivello et al., 2010. Cardiomyogenic differentiation of human bone marrow mesenchymal cells: Role of cardiac extract from neonatal rat cardiomyocytes. Differentiation, 79: 93-101.

Laurino, L., X.X.X. Wang, B.A. de la Houssaye, L. Sosa and S. Dupraz et al., 2005. PI3K activation by IGF-1 is essential for the regulation of membrane expansion at the nerve growth cone. J. Cell. Sci., 118: 3653-3662.

Leri, A., Y. Liu, P.P. Claudio, J. Kajstura and X.W. Wang et al., 1999. Insulin-like growth factor-1 induces $\mathrm{Mdm} 2$ and down-regulates p53, attenuating the myocyte renin-angiotensin system and stretchmediated apoptosis. Am. J. Pathol., 154: 567-580.

Li, Y.Z., D.Y. Lu, W.Q. Tan, J.X. Wang and P.F. Li, 2008. p53 initiates apoptosis by transcriptionally targeting the antiapoptotic protein ARC. Mol. Cell. Biol., 28: 564-574.

Li, Y.Z., X.L. Ge and X.H. Liu, 2009. The cardioprotective effect of postconditioning is mediated by ARC through inhibiting mitochondrial apoptotic pathway. Apoptosis, 14: 164-172.

Mercier, I., M. Vuolo, J.F. Jasmin, C.M. Medina and M. Williams et al., 2008. ARC (apoptosis repressor with caspase recruitment domain) is a novel marker of human colon cancer. Cell. Cycle., 7: 1640-1647.

Miyatake, T., N. Koyamada, W.W. Hancock, M.P. Soares and F.H. Bach, 1998. Urvival of accommodated cardiac xenografts upon retransplantation into cyclosporine-treated recipients. Transplantation., 65: 1563-1569.
Ripa, R.S., E. Jorgensen, Y.Z. Wang, J.J. Thune and J.C. Nilsson et al., 2006. Stem cell mobilization induced by subcutaneous granulocyte-colony stimulating factor to improve cardiac regeneration after acute ST-elevation myocardial infarction-result of the double-blind, randomized, placebo-controlled stem cells in myocardial infarction (STEMMI) trial. Circulation., 113: 1983-1992.

Stitt, T.N., D. Drujan, B.A. Clarke, F. Panaro and Y. Timofeyva et al., 2004. The IGF-1/PI3K/Akt pathway prevents short article expression of muscle atrophy-induced ubiquitin ligases by inhibiting FOXO transcription factors. Mol. Cell., 14: 395-403.

Subramaniam, S., N. Shahani, J. Strelau, C. Laliberte, R. Brandt, D. Kaplan and K. Unsicker, 2005. Insulinlike growth factor 1 inhibits extracellular signalregulated kinase to promote neuronal survival via the phosphatidylinositol 3-kinase/protein kinase A/c-Raf pathway. J. Neurosci., 25: 2838-2852.

Wakeno, M., T. Minamino, O. Seguchi, H. Okazaki and O. Tsukamoto et al., 2006. Long-term stimulation of adenosine $\mathrm{A} 2 \mathrm{~b}$ receptors begun after myocardial infarction prevents cardiac remodeling in rats. Circulation, 114: 1923-1932.

Yamashita, K., J. Kajstura, D.J. Discher, B.J. Wasserlauf, N.H. Bishopric, P. Anversa and K.A. Webster, 2001. Reperfusion-activated Akt kinase prevents apoptosis in transgenic mouse hearts overexpressing insulinlike growth factor-1. Circ. Res., 88: 609-614.

Zhang, Y.Q. and B. Herman, 2008. Expression and modification of ARC (apoptosis repressor with a CARD domain) is distinctly regulated by oxidative stress in cancer cells. J. Cell. Biochem., 104: 818-825. 